\title{
A new empirical correlation for estimating bubble point pressure using the genetic algorithm
}

\author{
Mohamad Heidarian, Masoud Karimnezhad, Mahin Schaffie, Mohammad Ranjbar \\ Shahid Bahonar University of Kerman, Faculty of Engineering, Department of Petroleum Engineering, \\ Young Researchers Society; Kerman, Iran; e-mail: mohamadheidarian64@yahoo.com
}

(C) 2017 Authors. This is an open access publication, which can be used, distributed and reproduced in any medium according to the Creative Commons CC-BY 4.0 License requiring that the original work has been properly cited.

Received: 2016-06-26; accepted: 2017-04-26

\begin{abstract}
In this paper, a new and more accurate correlation to predict bubble point pressure $\left(P_{b}\right)$ for Middle East crudes by using the genetic alorithm (GA) is attempted. For this purpose, a total of 286 data sets of different crude oils from Middle East reservoirs were used as training data for constructing the correlation. The general form of the correlation was found by several regressive examinations. To improve the correlation, the genetic algorithm was applied. To validate the correlation, 143 data sets of different crudes from Middle East reservoirs which were different from the training data were used as test data for calculating mean absolute relative error (MARE) and correlation coefficient $\left(R^{2}\right)$ between the predicted values from the proposed correlation and the experimental values. In addition, the MARE and $R^{2}$ were calculated for previous correlation in the test data. The results show that the proposed correlation is more accurate than all of the previous correlations exclusively for Middle East crudes.
\end{abstract}

Keywords: PVT properties, bubble point pressure, empirical correlation, Middle East, genetic algorithm

\section{INTRODUCTION}

The accurate determination of the PVT properties of the reservoir fluids, such as bubble point pressure $\left(P_{b}\right)$, solution gas oil ratio $\left(R_{s}\right)$ and oil formation volume factor $\left(B_{o b}\right)$, is necessary for the formation evaluation of hydrocarbon reserves, reservoir performance, production operations and the design of production facilities (Elsharkawy et al. 1995).

The PVT properties can be obtained by laboratory PVT tests or estimated by using empirical correlations. Although laboratory results provide a better accuracy where controlled conditions are imposed, the results are heavily dependent on the validity of the reservoir fluid samples, especially when the reservoir has been depleted below the bubble point pressure (Hemmati \& Kharrat 2007). In case no fluid samples are taken, the correlations can be used to estimate PVT data. This is particularly true during the early development phase where fluid properties are only available from surface flow tests (Dokla \& Osman 1992). In addition, the laboratory methods are too expensive and time consuming.

The bubble point pressure $\left(P_{b}\right)$ is one of the most important PVT properties. $P_{b}$ evaluation is an essential step in reservoir performance calculations and the design of various stages of oil field operations.

Because the laboratory methods are sometimes impossible for many reasons, several empirical correlations have been developed for PVT properties. Especially in the recent decades, there has been an increasing interest in developing new correlations for crude oils of different regions of the worlds. A review of the published $P_{b}$ correlations is summarized in Tables 1 and 2. According to Table 1, 
the majority of the current correlations have been proposed for specific regions. In addition, Table 2 shows that the used oil PVT properties of each region are different from those of the others.

Due to regional changes in crude oil compositions and properties, none of the correlations can be applied as an exact universal correlation. In this paper, by using the genetic algorithm, which is one the most powerful techniques of artificial intelligence in optimization, a new and more accurate correlation to predict $P_{b}$ of Middle East crudes has been proposed.

Table 1

$A$ review of the published $\mathrm{Pb}$ correlations

\begin{tabular}{|c|c|c|}
\hline Author & Correlation & Region \\
\hline Standing (1947) & $P_{b}=18.2\left[\left(\frac{R_{S}}{\gamma_{g}}\right) 0.8310^{\left(0.00091 T_{F}-0.0125 \gamma_{o}\right)}-1.4\right]$ & $\begin{array}{l}\text { California, } \\
\text { U.S.A. }\end{array}$ \\
\hline Vazquez \& Beggs (1980) & $\begin{array}{l}P_{b}=\left[27.64\left(\frac{R_{S}}{\gamma_{g}}\right) 10^{\left(-11.172 \frac{\left.\gamma_{o}{ }^{(} \mathrm{API}\right)}{T_{R}}\right)}\right]^{1.0937} . \text { For: } \gamma_{o\left({ }^{\circ} \mathrm{API}\right)} \leq 30 \\
P_{b}=\left[56.06\left(\frac{R_{S}}{\gamma_{g}}\right) 10^{\left(-10.393 \frac{\gamma_{o}\left({ }^{\circ} \mathrm{API}\right)}{T_{R}}\right)}\right]^{1.187} . \text { For: }: \gamma_{o\left({ }^{\circ} \mathrm{API}\right)}>30\end{array}$ & Worldwide \\
\hline Glaso (1980) & $\begin{array}{l}P_{b}=10^{\left[1.7669+1.7447 \log (G)-0.30218(\log (G))^{2}\right]} \text { and: } \\
G=\left(\frac{R_{S}}{\gamma_{g}}\right){ }^{0.816} T_{F}^{0.172} \gamma_{o\left({ }^{\circ} \mathrm{API}\right)}{ }^{-0.989}\end{array}$ & North Sea \\
\hline Al-Marhoun (1988) & $P_{b}=0.00538088 R_{s}^{0.715082} \gamma_{g}^{-1.877840} \gamma_{o}^{3.1437} T_{R}^{1.326570}$ & Middle East \\
\hline Dokla \& Osman (1992) & $\begin{array}{l}\text { Al-Marhoun (1988). New calculated constant: } \\
P_{b}=0.836386 \mathrm{e} 4 R_{s}^{0.724047} \gamma_{g}^{-1.01049} \gamma_{o}^{0.107971} T_{R}^{-0.952584}\end{array}$ & U.A.E. \\
\hline $\begin{array}{l}\text { Petrosky \& } \\
\text { Farshad (1993) }\end{array}$ & $\begin{array}{l}\text { Standing (1947). New calculated constants: } \\
P_{b}=112.727\left[\left(\frac{R_{S}^{0.5774}}{\gamma_{g}^{0.8439}}\right) 10^{X}-12.340\right] \\
X=0.00004561 T_{F}^{1.3911}-7.916 \mathrm{e}-4 \gamma_{o\left({ }^{\circ} \mathrm{API}\right)}^{1.5410}\end{array}$ & $\begin{array}{l}\text { Gulf of } \\
\text { Mexico }\end{array}$ \\
\hline Lasater (1958) & $\begin{array}{l}P_{b}=P_{t} \frac{T_{R}}{\gamma_{g}} \\
\left.P_{t}=0.38418-1.20081 Y_{g}+9.64868 Y_{g}^{2} \& Y_{g}=\left(\frac{R_{S}}{379,3}\right) / /\left(\frac{R_{S}}{379,3}\right)+\left(\frac{R_{S}}{M}\right)\right] \\
M=725.32143-16.03333 \gamma_{o(\mathrm{API})}+0.09524 \gamma_{o(\mathrm{API})^{2}}\end{array}$ & $\begin{array}{l}\text { Canada } \\
\text { West and } \\
\text { Midcontinent }\end{array}$ \\
\hline Omar \& Todd (1993) & $\begin{array}{l}\text { Standing (1947) correlation with one change: } \\
P_{b}=18.2\left[\left(\frac{R_{s}}{\gamma_{g}}\right) \times 10\left({ }^{\left.0.00091 T_{F}-0.0125 \gamma_{o}{ }^{(\mathrm{API}))}-1.4\right]}\right.\right. \\
X=1.4256-0.2608 B_{o b}-0.4596 \gamma_{g}+0.04481 B_{o b}{ }^{2}+0.2360 \gamma_{g}^{2}-\left(\frac{0.1077}{\gamma_{g} B_{o b}}\right)\end{array}$ & Malaysia \\
\hline $\begin{array}{l}\text { Farshad et al. (1996) } \\
\text { (correlation (1)) }\end{array}$ & $\begin{array}{l}\text { Standing (1947). New calculated constants: } \\
P_{b}=33.22\left[\left(\frac{R_{S}}{\gamma_{g}}\right){ }^{0.8283} 10^{\left(0.000037 T_{F}-0.0142 \gamma_{o}\right)}\right]\end{array}$ & Colombia \\
\hline
\end{tabular}


Table 1 cont.

\begin{tabular}{|c|c|c|}
\hline $\begin{array}{l}\text { Farshad et al. (1996) } \\
\text { (correlation (2)) }\end{array}$ & $\begin{array}{l}\text { Glaso }(1980) . \text { New calculated constants: } \\
P_{b}=10^{\left[0.3058+1.9013 \log G-0.26(\log G)^{2}\right]} \\
\text { and: } \\
\mathrm{G}=\gamma_{g}^{-1.378} R_{S}^{1.053} 10^{\left(0.00069 T_{F}-0.0208 \gamma_{o}{ }^{(\mathrm{A} A P I)}\right.}\end{array}$ & Colombia \\
\hline $\begin{array}{l}\text { Macary \& El- } \\
\text { Batanoney (1992) }\end{array}$ & $\begin{array}{l}P_{b}=204.257 K\left(R_{s}^{0.51}-4.7927\right) \\
K=\exp \left[0.00077 T_{F}-0.0097 \gamma_{o}-0.4003 \gamma_{g}\right]\end{array}$ & Gulf of Suez \\
\hline Almehaideb (1997) & $P_{b}=-620.592+6.23087\left(R_{S} \gamma_{o}\right) /\left(\gamma_{g} B_{o b}{ }^{1.38559}\right)+2.89868 T_{F}$ & U.A.E. \\
\hline $\begin{array}{l}\text { Kartoatmodjo \& } \\
\text { Schmidt (1994) }\end{array}$ & $\begin{array}{l}\text { Vazquez \& Beggs (1980). New calculated constants: } \\
P_{b}=\left\{R_{S} /\left[0.05958 \gamma_{g}^{0.7972} 10^{\left.\left(13.1405 \gamma_{o}{ }^{\left.\left({ }^{\circ} \mathrm{API}\right) / \mathrm{TR}\right)}\right]\right\}^{0.9986} . \text { For: } \gamma_{o\left({ }^{\circ} \mathrm{API}\right)} \leq 30}\right.\right. \\
P_{b}=\left\{R_{S} /\left[0.03150 \gamma_{g}^{0.7589} 10^{\left.\left(11.2895 \gamma_{o}{ }^{\left.\left({ }^{\circ} \mathrm{API}\right) / \mathrm{TR}\right)}\right]\right\}^{0.9143} \text {. For: } \gamma_{\left.o^{(} \mathrm{API}\right)}>30}\right.\right.\end{array}$ & Worldwide \\
\hline Al-Shammasi (2001) & $P_{b}=\gamma_{o}^{5.527215} \exp \left(-1.841408 \gamma_{o} \gamma_{g}\right)\left(R_{S} T_{R} \gamma_{g}\right)^{0.783716}$ & Worldwide \\
\hline Hanafy et al. (2005) & $P_{b}=3.205 R_{s}+157.27$ & Egypt \\
\hline $\begin{array}{l}\text { Hemmati \& } \\
\text { Kharrat (2007) }\end{array}$ & $\begin{array}{l}P_{b}=10.4566\left[\left(\frac{R_{S}}{\gamma_{g}}\right) \times 10^{\left[0.0008 T_{F}-0.0098 \gamma_{o}\right]}-8.6817\right] \\
X=1.5897-0.2735 B_{o b}-0.4429 \gamma_{g}+0.04649 B_{o b}^{2}+0.144 \gamma_{g}^{2}-0.1596\left[1 /\left(\gamma_{g} B_{o b}\right)\right]\end{array}$ & Iran \\
\hline \multicolumn{3}{|c|}{$\begin{array}{c}P_{b} \text { - bubble point pressure, Psi } \\
R_{s} \text { - solution gas oil ratio, SCF/STB } \\
T_{F} \text { - reservoir temperature, Fahrenh } \\
T_{R}-\text { reservoir temperature, Rankin } \\
\gamma_{o} \text { - specific oil gravity } \\
\gamma_{g} \text { - specific oil gravity, air }=1 \\
\gamma_{o\left({ }^{\circ} \mathrm{API} I\right.} \text { - specific oil gravity, API degree } \\
B_{o b}-\text { bubble point oil formation volu }\end{array}$} \\
\hline
\end{tabular}

Table 2

Data used in the development of published Pb correlations

\begin{tabular}{|l|c|c|c|c|c|c|}
\hline \multicolumn{1}{|c|}{ Author } & $\begin{array}{c}\text { Number of } \\
\text { used data }\end{array}$ & $\begin{array}{c}\text { Bubble point } \\
\text { pressure } \\
{[\text { Psi] }}\end{array}$ & $\begin{array}{c}\text { Reservoir } \\
\text { temperature } \\
{\left[{ }^{\circ} \text { F }\right]}\end{array}$ & $\begin{array}{c}\text { Solution } \\
\text { gas oil ratio } \\
{[\text { SCF/STB] }}\end{array}$ & $\begin{array}{c}\text { Tank oil } \\
\text { gravity } \\
{\left[{ }^{\circ} \text { API] }\right.}\end{array}$ & $\begin{array}{c}\text { Gas gravity } \\
\text { (air = 1) }\end{array}$ \\
\hline Standing (1947) & 105 & $130-7000$ & $100-258$ & $20-1425$ & $16.5-63.8$ & $0.59-0.95$ \\
\hline Vazquez \& Beggs (1980) & 6004 & $15-6055$ & $75-294$ & $0-2199$ & $15.3-59.3$ & $0.51-1.35$ \\
\hline Glaso (1980) & 41 & $165-7142$ & $80-280$ & $90-2637$ & $22.3-48.1$ & $0.65-1.28$ \\
\hline Al-Marhoun (1988) & 160 & $20-3573$ & $74-240$ & $26-1602$ & $19.4-44.6$ & $0.75-1.37$ \\
\hline Dokla \& Osman (1992) & 51 & $590-4640$ & $190-275$ & $181-2266$ & $28.2-40.3$ & $0.80-1.29$ \\
\hline Farshad et al. (1996) & 43 & $32-4138$ & $95-260$ & $6-1645$ & $18.0-44.9$ & $0.66-1.7$ \\
\hline Lasater (1958) & 158 & $48-5780$ & $82-272$ & $3-2905$ & $17.9-51.1$ & $0.57-1.2$ \\
\hline $\begin{array}{l}\text { Macary \& } \\
\text { El-Batanoney (1992) }\end{array}$ & 90 & $1200-4600$ & $130-290$ & $200-1200$ & $25-40$ & $0.70-1.00$ \\
\hline $\begin{array}{l}\text { Petrosky \& } \text { Farshad (1993) } \\
\text { Omar \& Todd (1993) }\end{array}$ & 90 & $1574-6523$ & $114-288$ & $217-1406$ & $16.3-45.0$ & $0.58-0.85$ \\
\hline $\begin{array}{l}\text { Kartoatmodjo \& } \\
\text { Schmidt (1994) }\end{array}$ & 5392 & $15-6055$ & $75-320$ & $0-2890$ & $14.4-58.9$ & $0.38-1.71$ \\
\hline Almehaideb (1997) & 62 & $501-4822$ & $190-306$ & $128-3871$ & $30.9-48.6$ & $0.75-1.12$ \\
\hline Al-Shammasi (2001) & 1709 & $0-6613.8$ & $58-341$ & $6-3298$ & $6-63.7$ & $0.511-3.445$ \\
\hline Hanafy et al. (2005) & 741 & $36-5003$ & $107-327$ & $7-4272$ & $17.8-47.7$ & $0.633-1.627$ \\
\hline $\begin{array}{l}\text { Hemmati \& } \\
\text { Kharrat (2007) }\end{array}$ & 287 & $248-5156$ & $77.5-290$ & $125-2189.25$ & $18.8-48.34$ & $0.523-1.415$ \\
\hline
\end{tabular}




\section{METHODOLOGY}

In this study, the genetic algorithm (GA) was used as the main tool for developing the correlation. The genetic algorithm is one of the powerful techniques of artificial intelligence in terms of optimization. Optimization is the process of adjusting the inputs to or characteristics of a device, mathematical process, or experiment to find the minimum or maximum output or results (Alenoghena et al. 2013). GA, which is based on the genetic process of biological organisms, is used to find a solution to a problem called objective function. A generated solution by the GA is called a chromosome and a collection of chromosomes is called a population. A chromosome is composed of genes. These chromosomes will undergo a process, which is called fitness function, to measure the suitability of the solution generated by GA with the problem. in the population, which has a higher fitness value will have a greater probability of being selected again in the next generation. After several generations, the chromosomes value will converge to a certain value which is the best solution for the problem (Mitchell 1999). Figure 1 shows the flowchart of the genetic algorithm.

The GA could be used for solving both constrained and unconstrained optimization problems (Karimnezhad et al. 2014). Furthermore, it can be applied to solve a variety of optimizations of problems that are not well suited for standard optimization algorithms (especially, problems in which the objective function is highly nonlinear).

In this paper, GA is applied to minimize the objective function to improve the accuracy of the proposed correlation. The proposed correlation is described in section "Verification of correlation".

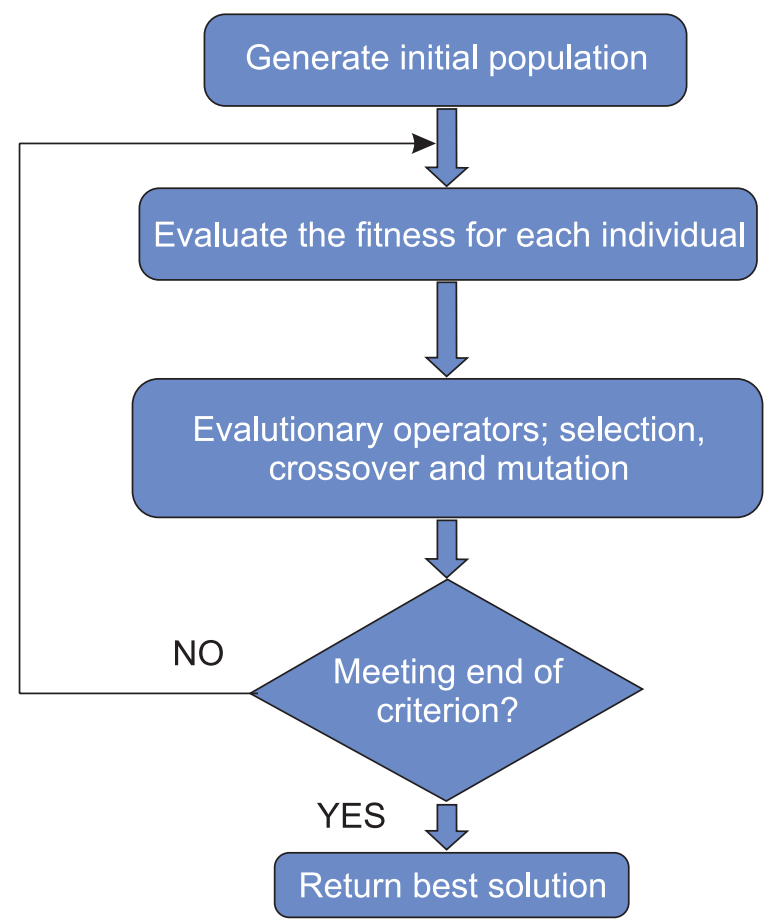

Fig. 1. Genetic algorithm flowchart (Ravandi et al. 2014)

Some chromosomes in the population will mate through a process called crossover thus producing new chromosomes named offspring which its genes composition is the combination of their parent. In a generation, a few chromosomes will undergo mutations in their gene. The chromosome

\section{DEVELOPMENT OF THE NEW CORRELATION}

Different Middle East oil fields were selected for this study. From these oil fields, 429 laboratory PVT analyses data were obtained and used. 
Table 3

Range of the data used

\begin{tabular}{|l|c|c|c|c|c|c|}
\hline \multirow{2}{*}{\multicolumn{1}{|c|}{ PVT property }} & \multicolumn{2}{|c|}{ Number of data } & \multicolumn{2}{c|}{ Range } & \multicolumn{2}{c|}{ Mean } \\
\cline { 2 - 8 } & $\begin{array}{c}\text { training } \\
\text { data }\end{array}$ & test data & $\begin{array}{c}\text { training } \\
\text { data }\end{array}$ & test data & $\begin{array}{c}\text { training } \\
\text { data }\end{array}$ & test data \\
\hline Tank oil gravity [ $\left.{ }^{\circ} \mathrm{API}\right]$ & 286 & 143 & $6.3-56.8$ & $6-52.03$ & 31.78 & 31.61 \\
\hline Reservoir temperature [ $\left.{ }^{\circ} \mathrm{F}\right]$ & 286 & 143 & $62.6-297$ & $59-306$ & 143.43 & 186.64 \\
\hline Solution gas oil ratio [SCF/STB] & 286 & 143 & $17.21-3020$ & $8.61-3298.66$ & 636.4 & 633.58 \\
\hline Bubble point pressure [Psi] & 286 & 143 & $130-6613.82$ & $107.33-6358.55$ & 2126.83 & 2157.25 \\
\hline Gas gravity (air $=1$ ) & 286 & 143 & $0.649-1.789$ & $0.624-1.53$ & 1.00 & 0.982 \\
\hline
\end{tabular}

The data sets were extracted from various papers (Glaso 1980, Al-Marhoun 1988, Dokla \& Osman 1992, Ghetto et al. 1994, Gharbi \& Elsharkawy 1997). The data sets were divided into two groups: one group including 286 data sets used as training data for constructing the correlation, and the other including 143 data sets used as test data for the correlation validation. The training and test data were selected randomly. The data consists of the reservoir temperature, bubble point pressure, oil and gas specific gravity and solution gas oil ratio within the ranges as shown in Table 3.

Bubble point pressure $\left(P_{b}\right)$ is a function of solution gas oil ratio $\left(R_{s}\right)$, temperature $(T)$, oil gravity $\left(\gamma_{o}\right)$ and gas gravity $\left(\gamma_{g}\right)$; in other words:

$P_{b}=f\left(T, R_{s}, \gamma_{o}, \gamma_{g}\right)$

For constructing an appropriate correlation, the training data sets were used. Several cases were examined to find an appropriate correlation between these parameters for $P_{b}$ prediction. After several regressive examinations, it was found that there is a powerful relationship between the independent parameters $\left(T, R_{s}, \gamma_{o}, \gamma_{g}\right)$ and $P_{b}$ as equation (2) (Fig. 2):

$P_{b}=7.9522\left[R_{s} \cdot\left(\gamma_{o} / \gamma_{g}\right)+T_{R} \cdot\left(\gamma_{g} / \gamma_{o\left({ }^{\circ A P I}\right)}\right]^{0.8747}\right.$

The correlation between experimental values and predicted values from equation (2) in the test data has been shown in Figure 3.

By the trial and error method, it was found that the accuracy of the equation (2) can improve if it is rewritten as equation:

$P_{b}=a_{1}\left[R_{S}^{a_{2}}\left(\gamma_{o} / \gamma_{g}\right)^{a_{3}}+T_{R}^{a_{4}}\left(\gamma_{g} / \gamma_{o\left({ }^{\circ} \mathrm{API}\right)}\right)^{a_{5}}\right]^{a_{6}}$

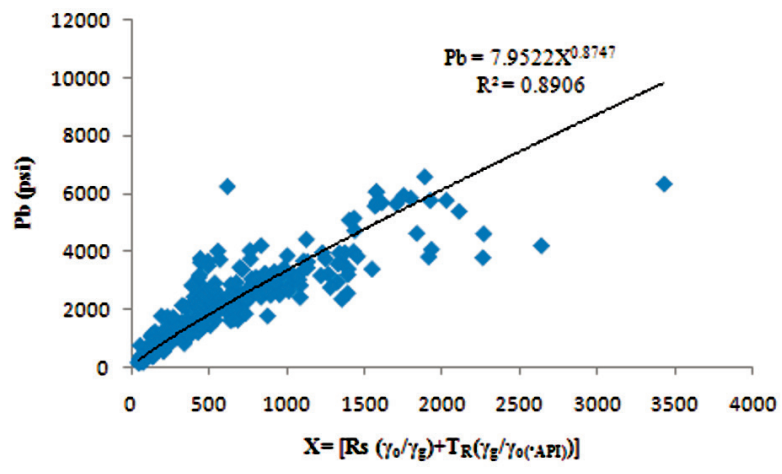

Fig. 2. Relationship between the independent parameters ( $T$, $\left.R_{s}, \gamma_{o}, \gamma_{g}\right)$ and $P_{b}$ (training data)

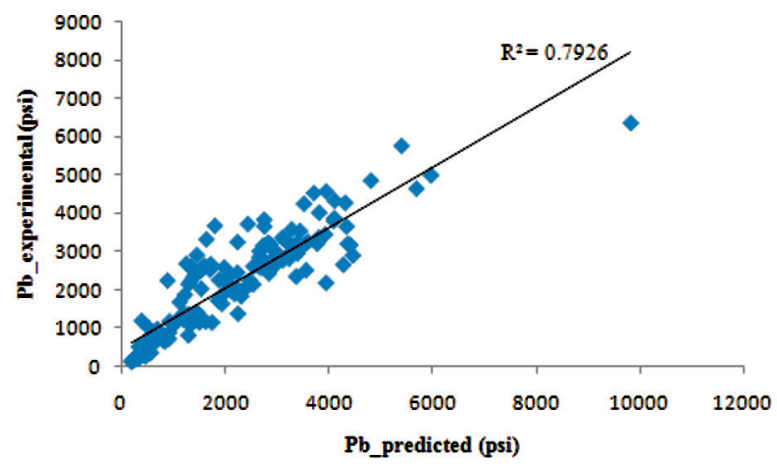

Fig. 3. The correlation between experimental $P_{b}$ values and predicted $P_{b}$ values from equation (2) (test data)

It is obvious that the accuracy of correlation (3) will be maximized if the constants $a_{1}$ through $a_{6}$ are optimal. To determine the constants $a_{1}$ through $a_{6}$ optimally, GA was applied. GA is one of the artificial intelligence techniques which can be used for both linear and nonlinear optimizations. GA minimizes the objective function. Objective function (or fitness function) is the function that must be optimized. 
Table 4

Parameters used in the GA

\begin{tabular}{|l|l|}
\hline \multicolumn{1}{|c|}{ GA parameter } & \multicolumn{1}{c|}{ GA parameters that used for prediction of $\boldsymbol{P}_{\boldsymbol{b}}$} \\
\hline Population & Population type: double vector; population size: 55 ; initial range: $[0 ; 1]$ \\
\hline Fitness scaling & Scaling function: rank \\
\hline Selection & Selection function: roulette \\
\hline Reproduction & Elite count: 3; crossover fraction: 0.85 \\
\hline Mutation & Mutation function: Gussian; shrink value: 1; scale: 0.1 \\
\hline Crossover & Crossover function: scattered \\
\hline Migration & Direction: forward; fraction: 0.8 ; interval: 40 \\
\hline Hybrid function & Hybrid function: fminsearch \\
\hline Algorithm setting & Initial penalty: 100 ; penalty factor: 980 \\
\hline Stopping criteria & Generation: 1000 ; time limit: inf; fitness limit: inf; stall generation: 1000 ; stall time limit: inf \\
\hline
\end{tabular}

To determine the constants $a_{1}$ to $a_{6}$ using GA, the fitness function is defined as equation:

Fitness function $=$

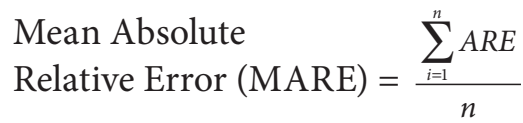

where:

$$
\begin{aligned}
& A R E=\frac{a b s\left(P_{\text {bexperimental }}-P_{b_{-} \text {predicted }}\right)}{P_{b_{-} \text {experimental }}}= \\
& =\frac{a b s\left(P_{b_{\text {_experimental }}}-a_{1}\left[R_{S}^{a_{2}}\left(\gamma_{o} / \gamma_{g}\right)^{a_{3}}+T_{R}^{a_{4}}\left(\gamma_{g} / \gamma_{o^{\circ} A P I}\right)^{a_{5}}\right]^{a_{G}}\right)}{P_{b \text { experimental }}}
\end{aligned}
$$

In equation (4), $P_{b_{-} \text {experimental }}$ and $P_{b_{-} \text {predicted }}$ are the experimental $P_{b}$ and the predicted $P_{b}$ by equation (3), respectively. Moreover, $n$ is the number of the used data, $a_{1}$ to $a_{6}$ are the constants which are predicted by the GA.

Parameters used to perform genetic algorithm are listed in Table 4.

The constants $a_{1}$ to $a_{6}$ were defined as vectors in order to accelerate the algorithm performance. In this case, the fitness function is called once instead of being called for each member and, therefore, its performance accelerates. The "fminsearch" which is a hybrid function was used to improve results obtained from the GA. After the end of the GA, the "fminsearch" which is an optimizer function uses genetic algorithm end point as its own starting point and is executed. This function improves the results.

Training data were used as input of GA to determine the constants $a_{1}$ through $a_{6}$. After adjusting the algorithm, it was run and the parameters were obtained as follows:

$a_{1}=6.15, a_{2}=1.015, a_{3}=1.05, a_{4}=1, a_{5}=1.5, a_{6}=1$.

Figure 4 shows the experimental and predicted $P_{b}$ from correlation (3) versus oil gravity in the training data. According to Figure 4, performance of the correlation (3) is not acceptable when the oil gravity is more than $27^{\circ} \mathrm{API}$. To solve this problem, the training data were divided into two groups based on the value of the oil gravity; one group included the training data sets with an oil gravity less than $27^{\circ} \mathrm{API}$, and the other included the training data sets with oil gravity more than $27^{\circ} \mathrm{API}$. Then, the GA were reused to determine the constants $a_{1}$ through $a_{6}$ for training data sets with oil gravity more than $27^{\circ} \mathrm{API}$. The final results are listed in Table 5.

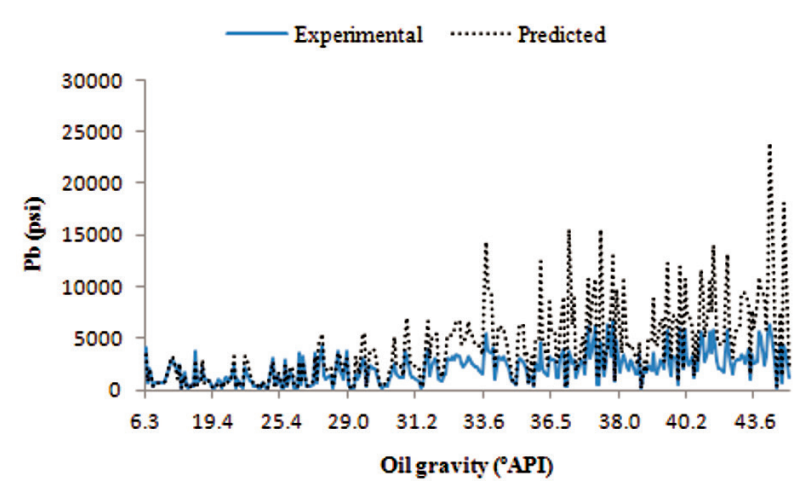

Fig. 4. Experimental and predicted $P_{b}$ from equation (3) versus oil gravity (training data) 
Table 5

The final proposed correlation and its constants

\begin{tabular}{|c|c|c|}
\hline \multirow{2}{*}{ Constant } & \multicolumn{2}{|c|}{$\boldsymbol{P}_{b}=\boldsymbol{a}_{1}\left[\boldsymbol{R}_{S}{ }^{a 2}\left(\gamma_{\boldsymbol{o}} / \gamma_{g}\right)^{a 3}+\boldsymbol{T}_{\boldsymbol{R}}{ }^{a 4}\left(\gamma_{g} / \gamma_{\left.\boldsymbol{o}^{\circ} \mathrm{API}\right)}\right)^{a 5}\right]^{a 6}$} \\
\cline { 2 - 3 } & $\mathbf{A P I} \leq 27$ & $\mathbf{A P I}>27$ \\
\hline$a_{1}$ & 6.15 & 17.8 \\
\hline$a_{2}$ & 1.015 & 0.735 \\
\hline$a_{3}$ & 1.05 & 1.25 \\
\hline$a_{4}$ & 1 & 0.9 \\
\hline$a_{5}$ & 1.5 & 2 \\
\hline$a_{6}$ & 1 & 1.01 \\
\hline
\end{tabular}

Figure 5 shows the experimental and predicted $P_{b}$ from the proposed correlation (based on the constants $a_{1}$ through $a_{6}$ which are listed in Table 5) versus oil gravity in the training data.

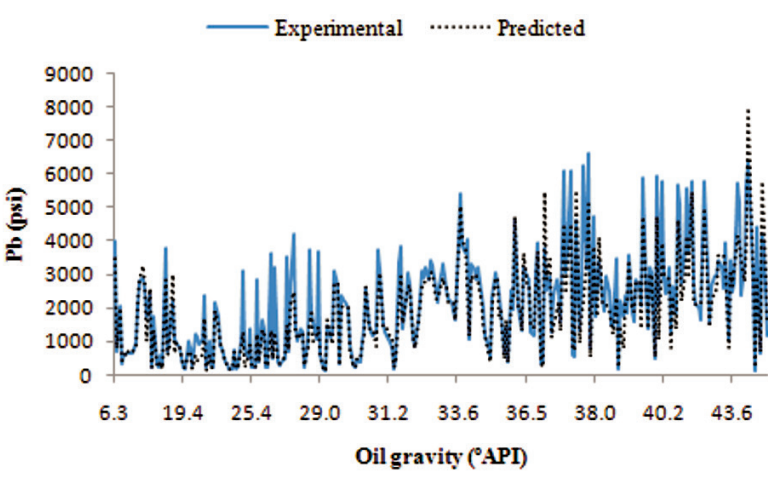

Fig. 5. Experimental and predicted $P_{b}$ from correlation (3) (based on the constantsa $a_{1}$ through $a_{6}$ which are listed in Table 5) versus oil gravity (training data)

\section{VERIFICATION OF CORRELATION}

For the verification of the proposed correlation, test data including 143 data sets were used. Figure 5 shows the experimental and predicted $P_{b}$ from the proposed correlation (based on the constants $a_{1}$ through $a_{6}$ which are listed in Table 5) versus oil gravity in the test data. In addition, the correlation between experimental values and predicted values from the correlation in the test data is shown by Figure 6 . According to the results presented in Figures 6 and 7, it seems that there is an acceptable agreement between predicted $P_{b}$ values from the proposed correlation and the experimental $P_{b}$ values.

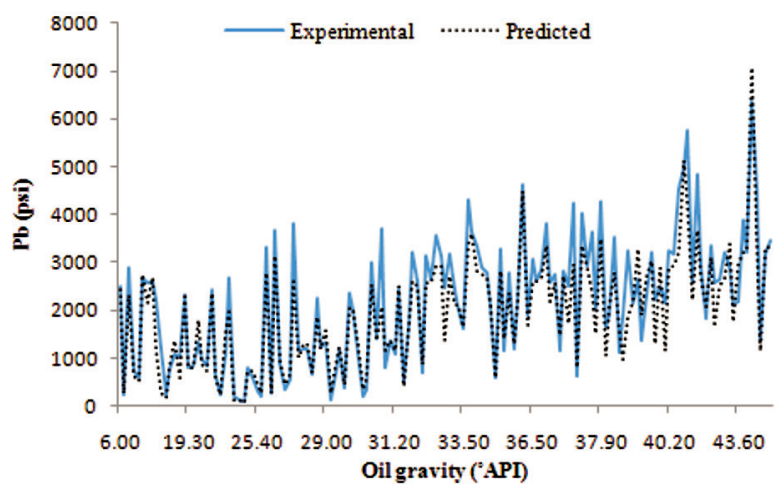

Fig. 6. Experimental and predicted $P_{b}$ from correlation (3) (based on the constants $a_{1}$ through $a_{6}$, (listed in Table 5) versus oil gravity (the test data)

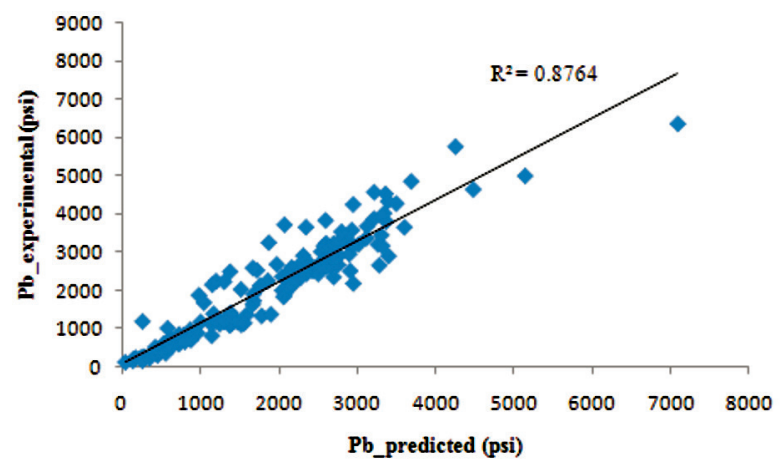

Fig. 7. The correlation between experimental values and predicted values from correlation 3 (based on the constants $a_{1}$ through $a_{6}$ listed in Table 5 (test data))

\section{RESULTS AND DISCUSSION}

In this study, a new emprical correlation was proposed to predict the bubble point pressure $\left(P_{b}\right)$ for Middle East crude oils. The genetic algorithm (GA) is the dominant tool used for developing the correlation. GA is a tool, which can be used for both linear and nonlinear optimizations. The initial form of the correlation was obtained by regressive examinations (Fig. 2). To improve the accuracy of the proposed correlation, training data were divided into two groups based on their oil gravity (one group included the training data sets with oil gravity less than $27^{\circ} \mathrm{API}$, and the other included the training data sets with oil gravity more than $27^{\circ} \mathrm{API}$ ) and the GA was used for optimization the constants of the correlation (constants $a_{1}$ through $a_{6}$ ). The proposed correlation and its obtained constants are listed in Table 5 .

The correlation coefficient $\left(R^{2}\right)$ between the experimental values and the predicted values from 
the proposed correlation in the test data was 0.874 , which reveals an acceptable agreement between the predicted and experimental values (Fig. 7). To evaluate the accuracy of the proposed correlation, Mean Absolute Relative Error (MARE) was also calculated. The MARE of the correlation in the test data was 0.1624 . In addition, the MARE and $R^{2}$ were calculated for previous correlation in the test data (Tab. 6). A comparison between the MARE and $R^{2}$ of the proposed correlation and previous correlations shows that the proposed correlation is much more accurate than all of the previous correlations.

The proposed correlation was developed for Middle East crudes. However, because it is more accurate than all of the previous correlations, it could be used as a universal correlation for the prediction of bubble point pressure.

\section{Table 6}

Mean Absolute Relative Error (MARE) and correlation coefficient $\left(R^{2}\right)$ for different correlations

\begin{tabular}{|l|c|c|c|}
\hline \multicolumn{1}{|c|}{ Author } & Year & MARE & $\boldsymbol{R}^{2}$ \\
\hline Standing & 1947 & 0.5366 & 0.7375 \\
\hline Petrosky \& Farshad & 1993 & 0.24095 & 0.8245 \\
\hline Lasater & 1958 & 0.3978 & 0.8131 \\
\hline Vazquez \& Beggs & 1980 & 0.946 & 0.7440 \\
\hline Glaso & 1980 & 0.3445 & 0.7616 \\
\hline Al-Marhoun & 1988 & 0.382 & 0.7778 \\
\hline Dokla \& Osman & 1992 & 0.301 & 0.7858 \\
\hline $\begin{array}{l}\text { Farshad et al. } \\
\text { (correlation (1)) }\end{array}$ & 1996 & 0.2329 & 0.8467 \\
\hline $\begin{array}{l}\text { Farshad et al. } \\
\text { (correlation (2)) }\end{array}$ & 1996 & 0.3802 & 0.8052 \\
\hline Macary \& El-Batanoney & 1992 & 0.2335 & 0.812 \\
\hline Omar \& Todd & 1993 & 0.9497 & 0.7907 \\
\hline $\begin{array}{l}\text { Kartoatmodjo } \\
\text { \& Schmidt }\end{array}$ & 1994 & 0.27 & 0.7687 \\
\hline Almehaideb & 1997 & 1.703 & 0.7778 \\
\hline Al-Shammasi & 2001 & 0.2623 & 0.8172 \\
\hline Hanafy et al. & 2005 & 0.3327 & 0.71843 \\
\hline Hemmati \& Kharrat & 2007 & 0.4438 & 0.7718 \\
\hline
\end{tabular}

\section{CONCLUSIONS}

1. In this study, a new empirical correlation has been proposed to predict the bubble point pressure $\left(P_{b}\right)$ for Middle East crude oils. The genetic algorithm (GA), which is one of the most powerful techniques of the artificial intelligence in optimization, has been used to develop the correlation.

2. The proposed correlation is a nonlinear function of temperature, solution gas oil ratio, and oil and gas gravity. To evaluate its accuracy, the Mean Absolute Relative Error (MARE) and correlation coefficient $\left(R^{2}\right)$ between predicted values from the proposed correlation and experimental values in the test data were calculated. The MARE and $R^{2}$ in the test data were 0.1624 and 0.874 , respectively.

3. The comparison between the MARE and $R^{2}$ of the proposed correlation and previous correlations shows that the proposed correlation is more accurate than all of the previous correlations.

4. The correlation was developed exclusively for Middle East crudes. However, because it is more accurate than all of the previous correlations, it could be used as a universal correlation for the prediction of $P_{b}$.

\section{REFERENCES}

Alenoghena C.O., Emagbetere J.O. \& Edeko F.O., 2013. Application of Genetic Algorithm in Radio Network Coverage Optimization - A Review. International Journal of Computer Applications, 66, 48-52.

Al-Marhoun M.A., 1988. PVT correlations for Middle East crude oils. Journal of Petroleum Technology, 40, 650-666.

Almehaideb R.A., 1997. Improved PVT correlations for UAE crude oils. [in:] The SPE Middle East Oil Show, 15-18 March 1997, Manama, Bahrain, SPE-37691-MS, Society of Petroleum Engineers.

Al-Shammasi A.A., 2001. A review of bubble point pressure and oil formation volume factor correlations. SPE Reservoir Evaluation \& Engineering, 4, 2, 146-160.

Dokla M. \& Osman M., 1992. Correlation of PVT properties for UAE crudes. SPE Formation Evaluation, 7, 41-46.

Elsharkawy A.M., Elgibaly A.A \& Alikhan A.A, 1995. Assessment of the PVT correlations for predicting the properties of the Kuwaiti crude oils. Journal of Petroleum Science and Engineering, 13, 219-232.

Farshad F., LeBlanc J.L., Garber J.D. \& Osorio J.G., 1996. Empirical PVT correlations for Colombian crude oils. [in:] IV LAPEC: Proceedings of the Fourth Latin American and Caribbean Petroleum Engineering Conference: Port of Spain, Trinidad and Tobago, April 23-26, 1996, SPE-36105-MS, Society of Petroleum Engineers.

Gharbi R.B. \& Elsharkawy A.M., 1997. Neural Network Model for Estimating the PVT Properties of Middle East Crude Oils. [in:] The SPE Middle East Oil Show, 15-18 March 1997, Manama, Bahrain, SPE-37695-MS, Society of Petroleum Engineers. 
Ghetto G.D., Paone F. \& Villa M., 1994. Reliability Analysis on PVT Correlations. [in:] European Petroleum Conference, 25-27 October, London, United Kingdom, SPE-28904-MS, Society of Petroleum Engineers.

Glaso O., 1980. Generalized pressure-volume-temperature correlations. Journal of Petroleum Technology, 32, 785795.

Hanafy H.H., Macary S.M., Elnady Y.M., Bayomi A.A. \& El-Batanony M.H., 2005. Application of empirical PVT correlations exemplify significance of developing regional correlations - a new approach. [in:] Offshore Mediterranean Conference and Exhibition, 16-18 March 2005, Ravenna, Italy, OMC-2005-054.

Hemmati M.N. \& Kharrat R., 2007. A correlation approach for prediction of crude oil PVT properties. [in:] The SPE Middle East Oil and Gas Show and Conference, 11-14 March 2007, Manama, Bahrain, SPE-104543-MS, Society of Petroleum Engineers.

Karimnezhad M., Heidarian M., Kamari M. \& Jalalifar H., 2014. A new empirical correlation for estimating bubble point oil formation volume factor. Journal of Natural Gas Science and Engineering, 18, 329-335.

Kartoatmodjo T. \& Schmidt Z., 1994. Large data bank improves crude physical property correlations. Oil and Gas Journal, 92, 27, 51-55.

Lasater J.S., 1958. Bubble point pressure correlation. Journal of Petroleum Technology, 10, 65-67.
Macary S.M. \& El-Batanoney M.H., 1992. Derivation of PVT correlations for the Gulf of Suez crude oils. [in:] $11^{\text {th }} P e-$ troleum Exploration and Production Conference, 12-14 March 1992, Egypt, Cairo, EGPC.

Mitchell M., 1998. An Introduction to Genetic Algorithms. $5^{\text {th }}$ ed., The MIT Press, Cambridge, Massachusetts, London.

Omar M.I. \& Todd A.C., 1993. Development of new modified black oil correlations for Malaysian crudes. [in:] The SPE Asia Pacific Oil and Gas Conference, 8-10 February 1993, Singapore, SPE-25338-MS, Society of Petroleum Engineers.

Petrosky G. \& Farshad F., 1993. Pressure-volume-temperature correlation for the Gulf of Mexico. [in:] The SPE Annual Technical Conference and Exhibition, 3-6 October, Houston, Texas, SPE-26644-MS, Society of Petroleum Engineers.

Ravandi Gh.E., Nezamabadi-Pour H., Monfared A.E. \& Jaafarpour A.M., 2014. Reservoir Characterization by a Combination of Fuzzy Logic and Genetic Algorithm. Petroleum Science and Technology, 32, 840-847.

Standing M.B., 1947. A pressure volume temperature correlation for mixture of California oils and gases. [in:] API Drilling and Production Practice, API-47-275, Dallas, 275-287.

Vazquez M. \& Beggs H.D., 1980. Correlation for fluid physical property prediction. Journal of Petroleum Technology, 32, 968-970. 